\title{
A New Watershed? Re-evaluating Banković in Light of Al-Skeini
}

\author{
Anna Cowan
}

\section{Introduction}

Issues surrounding the extraterritorial reach of human rights treaties, particularly the European Convention on Human Rights (ECHR), have become highly pertinent in the context of military operations abroad, such as the UK occupation and military action in Iraq. ${ }^{1}$ Until recently, the major authority on the extraterritorial application of the ECHR was the controversial decision of the European Court of Human Rights in Banković v Belgium in 2001. ${ }^{2}$ The Court dismissed a claim against 17 NATO states for deaths and injuries caused by a NATO airstrike in Belgrade during the Kosovo crisis, on the basis that the jurisdictional threshold in ECHR Article 1 was not met.

Article 1 requires that states parties secure the rights and freedoms in the Convention to "everyone within their jurisdiction". This is a necessary condition for the application of the Convention: either the Convention applies or it does not. It is established that the notion of jurisdiction in Article 1 is

\footnotetext{
* Research Associate to Professor James Crawford, Lauterpacht Centre for International Law, University of Cambridge. This piece was inspired by research undertaken to assist Professor Crawford in preparing for the annual Baha Mousa Memorial Lecture, given in London on 13 September 2011.

11950 Convention for the Protection of Human Rights and Fundamental Freedoms, 2137 UNTS 171. See generally: F. Coomans \& M. Kamminga (eds), Extraterritorial Application of Human Rights Treaties (Intersentia, 2004); M. Dennis, 'Application of Human Rights Treaties Extraterritorially in Times of Armed Conflict and Military Occupation', (2005) 99 AJIL 119; R. Wilde, 'Legal "Black Hole"? Extraterritorial State Action and International Treaty Law on Civil and Political Rights', (2005) 26 Mich JIL 639; M. Gondek, The Reach of Human Rights in a Globalising World: Extraterritorial Application of Human Rights Treaties (Intersentia, 2009); M. Milanović, Extraterritorial Application of Human Rights Treaties (Oxford University Press, 2011). 2 (2001) 123 ILR 94.
} 
primarily territorial ${ }^{3}$ but the exceptions to that general rule are not entirely settled. The question is, in what circumstances do persons affected by the act of a state that takes place or has effects outside that state's national borders fall within the state's jurisdiction under Article 1?

Lord Brown described Banković as a "watershed authority in the light of which the Strasbourg jurisprudence as a whole has to be re-evaluated". ${ }^{4}$ However, on 7 July 2011 the European Court released its landmark judgment in Al-Skeini and Others $v U K,{ }^{5}$ finding that six Iraqi civilians killed in Iraq during incidents involving British soldiers were within the jurisdiction of the UK for the purposes of ECHR Article 1, and that the UK had breached the ECHR in five of the six cases. The judgment in Al-Skeini casts the findings in Banković in a new light, and now Banković itself falls to be re-evaluated.

This note analyses the reasoning in the two cases and concludes that although at first glance they may appear to be inconsistent, the decisions are not irreconcilable. It seems doubtful that the Court would reach a different result if given a chance to revisit the facts of Banković in the wake of Al-Skeini. Nonetheless, Al-Skeini provides some useful clarification of this murky area of law and, although not perfect, the decision will likely impact significantly on the interpretation of Article 1 jurisdiction in future cases. Space does not permit an in-depth review of the vast literature and jurisprudence in this area, so the analysis is confined primarily to these two cases alone.

\section{Banković}

The NATO airstrike on the Radio Televizija Srbije building in Belgrade during the Kosovo crisis in 1999 killed 16 people and injured 16 others. Claims were brought against 17 respondent states, all members of NATO and parties to the ECHR, alleging violations of Articles 2 (the right to life), 10 (freedom of expression) and 13 (right to an effective remedy).

The Court found that the case fell beyond the scope of Article 1 and was inadmissible. For the Convention to apply, the victims and/or the applicants needed to have been within the jurisdiction of the respondents when the incident occurred. The fact that an individual had been affected by an act committed by a state party or its agents was insufficient to establish the jurisdictional link. In concluding that the threshold condition of jurisdiction

\footnotetext{
3 Ibid., paras. 59-61.

${ }^{4} R$ (Al-Skeini) v Secretary of State for Defence [2004] EWHC 2911 (Admin), para. 267.

5 [2011] ECHR 55721/07.
} 
had not been met, the Court made three major findings on the meaning of jurisdiction under Article 1 as applicable in extraterritorial cases.

First, the concept of jurisdiction under Article 1 had to be interpreted consistently with the ordinary meaning of jurisdiction under international law, which is essentially a territorial notion. ${ }^{6}$ At the time of the attack, the victims and the applicants were in the Federal Republic of Yugoslavia (FRY), outside the territory of any of the respondent states. The Court observed that it had accepted "only in exceptional cases" that acts of the parties performed or producing effects outside their territory could constitute an exercise of their jurisdiction for Article 1 purposes. ${ }^{7} \quad$ Each case alleging extraterritorial jurisdiction would require special justification.

One recognised justification is when acts of the authorities of a state are performed or produce effects outside the territory of that state ("the state agent authority exception"). ${ }^{8}$ A second recognised justification arises where a state exercises effective control over an area outside its national territory as a result of military action ("the effective control exception"). ${ }^{9}$ After discussing these exceptions (and others not mentioned here), the Court in Banković summarised the exceptional recognition of extraterritorial jurisdiction as having occurred in cases when the state exercised all or some of the public powers normally exercised by the government of the territory. ${ }^{10}$ It held that neither recognised exception applied on the facts.

The second important finding in Banković was that Convention rights could not be "divided and tailored" according to the particular circumstances of the extraterritorial act in question. ${ }^{11}$ The applicants had argued that the respondents had effective control over FRY airspace and, as a special application of the effective control exception, they were bound to secure ECHR rights in the territory to an extent proportionate to the degree of control over the airspace. The Court rejected this argument, holding that the positive obligation in Article 1 required each state party to secure the entire range of substantive rights to those within its jurisdiction.

\footnotetext{
${ }^{6}$ Banković, supra note 2, paras. 59-61.

7 These are the Court's words (ibid., para. 67), but the question under Article 1 is not whether a certain act amounted to an "exercise of jurisdiction" by the state. The question is whether the applicants were "within the jurisdiction" of the state at the time- "jurisdiction" has more than one meaning. See M. Milanović, 'From Compromise to Principle: Clarifying the Concept of State Jurisdiction in Human Rights Treaties', (2008) 8 HRLR 411.

${ }^{8}$ Banković, supra note 2, para. 69.

9 Ibid., para. 70.

${ }^{10}$ Ibid., para. 71.

${ }^{11}$ Ibid., para. 75.
} 
Thirdly, the Court rejected an argument that denying the application of the ECHR in Bankovic would defeat the Convention's ordre public mission and leave a vacuum in its protection. ${ }^{12}$ In previous extraterritorial cases involving the actions of the Turkish army in Northern Cyprus, the Court had held that an inadmissibility ruling would deny the applicants the protections of the Convention to which they would otherwise have been entitled. ${ }^{13}$ However, those cases were distinguishable because Cyprus, a party to the Convention, had been unable to fulfil its obligations while Turkey (also a party) was in control of the area. The same problem did not arise in Banković because the FRY was not a party to the Convention. The Court observed that the Convention operated in an essentially regional context, and was not designed to be applied throughout the world. In this way the Court appeared to limit the Convention's extraterritorial application to those areas within the regional legal space ("espace juridique") of the Convention, this being the territories of the member states of the Council of Europe.

Banković has been the cause of some confusion in the case law and the subject of considerable criticism. ${ }^{14}$ Following the Strasbourg judgment in Al-Skeini, it is timely to re-assess the Court's position on the three central issues in Bankovic in relation to extraterritoriality: the exceptions to territorial jurisdiction, the indivisibility point, and the Convention's regional scope. But first, a brief introduction to the background to the Al-Skeini judgment is in order.

\section{Al-Skeini}

Al-Skeini was brought before the European Court in 2007 by relatives of six Iraqi civilians killed in incidents involving British soldiers in south-east Iraq. The deaths occurred between May and November 2003, while the UK was an occupying power in that region. The relatives of the first, second and fourth applicants were shot by British soldiers whose identities were known. The

\footnotetext{
${ }^{12}$ Ibid., paras. $79-80$.

${ }^{13}$ See e.g. Loizidou v Turkey (1996) 108 ILR 443 (merits); Cyprus v Turkey (2001) 120 ILR 10, para. 78.

${ }^{14}$ See e.g. R. Lawson, 'Life after Banković: On the Extraterritorial Application of the European Convention on Human Rights', in Coomans \& Kamminga, supra note 2, at 83; K. Altiparmak, 'Banković: An Obstacle to the Application of the European Convention on Human Rights in Iraq?', (2004) 9 JCSL 213; E. Roxstrom, M. Gibney \& T. Einarsen, 'The NATO Bombing Case (Banković et al. v. Belgium et al.) and the Limits of Western Human Rights Protection', (2005) 23 Boston UILJ 55; M. Milanović, supra note 7.
} 
third applicant's wife was shot and fatally wounded during an exchange of fire between a British patrol and a group of unknown gunmen, outside a building where the victim and her family were having dinner. The fifth applicant's son drowned, after allegedly being arrested by British soldiers, beaten and forced into a river. The sixth applicant's son, Baha Mousa, died as a result of ill-treatment while in British custody at a military base in Basrah.

\subsection{Procedural Background}

On 26 March 2004 the UK Secretary of State for Defence decided not to conduct independent inquiries into the deaths of the applicants' relatives (and of seven other Iraqi civilians), not to accept liability for the deaths, and not to pay just satisfaction. The 13 claimants applied for judicial review of this decision, and the matter proceeded through the domestic courts.

The judicial review application alleged violations of the procedural and substantive obligations of ECHR Article 2 (right to life) and, in Mr Mousa's case, violations of Article 3 (prohibition of torture). The Divisional Court proceeded with six test cases, and stayed the other seven (including that of the fifth applicant) pending resolution of the preliminary cases. ${ }^{15}$ Citing Banković, the Court found that the effective control exception to the essentially territorial jurisdiction in Article 1 did not apply in Iraq because the Convention operated essentially within its own regional space. Accordingly, it rejected the claims of the first four applicants on the grounds that the UK did not have jurisdiction over the relatives of those applicants at the time of their deaths. However, the Court held that if it was wrong on the jurisdictional question, and the claims did come within the scope of Article 1, then the investigative duty under Article 2 had been violated. In Baha Mousa's case, the Divisional Court held that the operation of a military prison outside UK territory with the consent of the Iraqi authorities came within the narrow state agent authority exception to territorial jurisdiction, and found a breach of the investigative duty under Articles 2 and 3 of the Convention.

The first four applicants appealed the finding that their relatives were not within UK jurisdiction when they died, and the Secretary of State crossappealed the finding in relation to Mr Mousa. In December 2005 the Court of Appeal dismissed both the appeals and the cross-appeal, upholding the decision of the Divisional Court in respect of the first four applicants. ${ }^{16}$ It remitted

\footnotetext{
15 [2004] EWHC 2911 (Admin).

${ }^{16}$ [2005] EWCA Civ 1609.
} 
Mr Mousa's case back to the Divisional Court to be reconsidered after the conclusion of court-martial proceedings against a number of soldiers connected to his death. Brooke LJ reviewed the Strasbourg jurisprudence on extraterritorial jurisdiction and concluded that a state could exercise jurisdiction outside its territory in circumstances of "state agent authority", and when it had effective control of an area beyond its borders. He said that the first exception could apply outside the espace juridique of the Council of Europe and regardless of whether or not the host state consented. Mr Mousa was under the control and authority of UK agents in Iraq when he died, but the other victims were not, and it was "quite impossible" to hold that the UK had effective control over the area at the relevant time.

The matter proceeded to the House of Lords in $2007 .{ }^{17}$ Again, a majority held that the UK did not have jurisdiction in the cases of the first four applicants. Lord Brown relied on Bankovic to reject a wide view of jurisdiction put forward by the applicants on the basis of a later ECHR decision, Issa $v$ Turkey. ${ }^{18}$ He stated that the applicants' interpretation would either extend the effective control principle beyond the Convention's regional space, contrary to Strasbourg precedent, or would stretch the state agent authority exception to breaking point and make the principle of effective control redundant. He emphasised the dicta in Banković that the jurisdiction in Article 1 cannot be "divided and tailored", and observed that:

except where a state really does have effective control of territory, it cannot hope to secure Convention rights within that territory and, unless it is within the area of the Council of Europe, it is unlikely in any event to find certain of the Convention rights it is bound to secure reconcilable with the customs of the resident population. ${ }^{19}$

The House of Lords did not need to consider the jurisdictional issue in relation to Mr Mousa's death, because the parties had agreed that his case should be remitted to the Divisional Court as ordered by the Court of Appeal, but Lord Brown (with whom the majority agreed) observed that he would recognise the UK's jurisdiction over Mr Mousa on the narrow basis relied upon by the

\footnotetext{
${ }^{17}$ Al-Skeini and Others $v$ Secretary of State for Defence [2007] UKHL 26.

18 [2004] ECHR 31821/96.

${ }^{19}$ Al-Skeini v Secretary of State for Defence, supra note 17, para. 129.
} 
Divisional Court: "essentially by analogy with the extra-territorial exception made for embassies" ${ }^{20}$

\subsection{The European Court's Decision}

In Strasbourg, the six applicants argued that their relatives had been within UK jurisdiction when they were killed, and that there had been no effective investigation into the deaths, in violation of Article 2 of the Convention. Unlike the UK courts, the European Court unanimously held that there was a sufficient jurisdictional link for the purposes of Article 1, in all six cases. It ultimately found a violation of the procedural duty to carry out an effective investigation into the deaths, in accordance with Article 2, in all cases except that of $\mathrm{Mr}$ Mousa. In Mr Mousa's case the Court noted that a full public inquiry has been

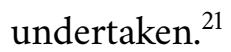

The Al-Skeini judgment is significant for its treatment of the three major issues in Banković: exceptions to territoriality, the indivisibility of Convention rights, and the relevance of the Convention's regional espace juridique. To deal with these in reverse order, Al-Skeini makes it clear that jurisdiction under Article 1 is not necessarily restricted to the regional "legal space" of the Convention. ${ }^{22}$ This finding contrasts strongly with the manner in which Banković was interpreted and applied by the UK courts.

Secondly, addressing the indivisibility issue, the Court clarified that when a state has jurisdiction over an individual, it has an obligation to secure the rights and freedoms that are relevant to that individual's particular situation. In that sense, the rights and obligations in the Convention can be "divided and tailored" to individual circumstances, ${ }^{23}$ despite the finding in Banković.

Finally, and crucially for the outcome of the case, the Court developed the state agent authority exception to territorial jurisdiction. The Court started by reiterating the Banković position that jurisdiction in Article 1 is essentially territorial, and acts performed or with effects outside national territory will come within Article 1 jurisdiction only in exceptional cases. The Court emphasised that each case must be determined on its particular facts, and stated that the principle of state agent authority as it appeared in previous cases (including Banković) is very broad, requiring an examination of the case-law to

\footnotetext{
${ }^{20}$ Ibid., para. 132. An interesting analogy between a military detention centre and an embassy.

${ }^{21}$ The final report of the inquiry was published on 8 September 2011 and is available at <http://www.bahamousainquiry.org/report/index.htm> [last accessed 2 May 2012].

${ }^{22}$ Al-Skeini v UK, supra note 5, paras. 141-2.

${ }^{23}$ Ibid., para. 137.
} 
identify the defining principles. It referred to Bankovic for the proposition that jurisdiction may arise if a state is exercising all or some of the public powers normally to be exercised by the government of the territory in question, through the consent, invitation or acquiescence of that government, and if the acts giving rise to Convention liability are attributable to the former state rather than the latter. Then, citing examples from its own jurisprudence, the Court held that in certain circumstances, the use of force against an individual by a state's agents operating outside its territory may bring that individual within the control of the state's authorities and into the state's Article 1 jurisdiction. The decisive element was said to be the exercise by state agents of physical power and control over the person in question. ${ }^{24}$

The Court concluded that at the time the applicants' relatives died, the UK had assumed in South East Iraq the exercise of some of the public powers that would normally be exercised by the sovereign government, particularly responsibility for the maintenance of security as well as civil law and order. ${ }^{25}$ In these exceptional circumstances, the Court considered that the UK (through its soldiers) exercised authority and control over individuals killed in the course of its security operations, and that this authority and control established the necessary jurisdictional link required by Article 1 of the Convention. ${ }^{26}$

This was an application of the "physical power and control" form of the state agent authority exception that the Court had articulated earlier in its judgment. The Court did not expressly rule on whether or not the UK was in effective control of the territory at the relevant time, beyond observing that the applicability of the effective control exception will be a question of fact in each case. After finding that the requisite jurisdictional link was established, the Court found that the UK had violated its Convention obligation to conduct effective and independent investigations, as the corollary of the right to life in ECHR Article 2, in all but Mr Mousa's case. ${ }^{27}$

\section{Reconciling Al-Skeini with Banković}

As summarised, Al-Skeini and Banković appear to diverge sharply on three central issues of extraterritoriality: the relevance of the Convention's legal space, the question of indivisibility, and the extent and application of the

\footnotetext{
${ }^{24}$ Ibid., paras. 133-6.

${ }^{25}$ Ibid., paras. $143-8$.

${ }^{26}$ Ibid., para. 149.

${ }^{27}$ Ibid., paras. $168-77$.
} 
exceptions to territoriality. It is striking that the Strasbourg decision and those of the UK courts in Al-Skeini show such different conclusions when each purported to rely heavily on Banković. Can the differences between the decisions be reconciled, or is one (or both) of them wrong? In my view, both cases were correctly decided on their facts, and their differences are not as extreme as appearances suggest, but the lack of clarity and consistency in the legal reasoning will continue to be problematic for the future development of the law.

\subsection{Espace Juridique}

The apparently opposite views on the significance of the Convention's regional legal space can be resolved relatively simply. The UK courts read Banković as confining the extraterritorial reach of the ECHR to European states, and barring its application in states outside the combined territory of the parties. The decision undoubtedly emphasised the essentially regional context and design of the Convention, but the UK courts' interpretation goes further than the language of Banković. The finding about the regional context of the ECHR in that case was made in response to an argument that a ruling of inadmissibility would create a vacuum in the legal protection of the Convention. By the time it addressed this argument in its judgment, the Court had already decided that there was no support for applying one of the recognised exceptions to territorial jurisdiction on the facts of the case.

Thus, the Court in Bankovic did not use the regional scope of the ECHR as a ground for denying a finding that the state had jurisdiction, as the UK courts did. It made the point about espace juridique in order to confirm that its decision would not create an unacceptable result, by denying protection that would otherwise have been available to the applicants. As Al-Skeini pointed out, the Court in Banković did not say the Convention could never apply outside the region; it simply said that the desirability of avoiding a vacuum in protection had so far been relied upon only where the territory in question would otherwise be covered. In other cases decided since Banković the European Court has recognised the possibility of jurisdiction outside the European states. ${ }^{28}$ Textually there is no necessary inconsistency between Banković and Al-Skeini; it is the interpretation of Banković by the UK courts that

\footnotetext{
${ }^{28}$ See e.g. Issa v Turkey, supra note 18, para. 74; Al-Saadoon and Mufdhi v UK [2009] ECHR 61498/08 (admissibility decision), paras. 84-9; Medvedyev v France [2010] ECHR 3394/03, paras. $62-7$.
} 
has contributed to the confusion. ${ }^{29}$

\subsection{Indivisibility}

As noted above, Banković said that Convention rights cannot be divided and tailored to match the circumstances of individual cases, and that if somebody is within a state party's jurisdiction, that state party must secure the full range of substantive Convention rights to that person. Al-Skeini qualified this by finding that states are obliged to secure the rights that are relevant to the individual circumstances, and that, in that sense, the rights can be divided and tailored.

The significance of this qualification should not be exaggerated. The Court in Al-Skeini was not advocating a "cherry-picking" approach to rights protection; a state could not rely on this finding to justify choosing to protect the right to freedom of expression while ignoring its obligations to respect family life. The point is simply that, for example, if a person is not subject to any judicial proceedings while within the state's jurisdiction, then his right to a fair trial in ECHR Article 6 is not relevant and does not need to be "secured" by the state. As Judge Bonello observed:

Extraterritorially, a Contracting State is obliged to ensure the observance of all those human rights which it is in a position to ensure. ... [i]t ill suits the respondent Government to argue, as they have, that their inability to secure respect for all fundamental rights in Basrah, gave them the right not to respect any at all. ${ }^{30}$

It is unlikely that the argument of the applicants in Bankovic about the obligation to secure rights being proportionate to the degree of control over the territory (in that case just the airspace) ${ }^{31}$ would succeed after Al-Skeini. As such, it could not be said that the Al-Skeini decision overrules or is inconsistent with Banković on the question of indivisibility.

\footnotetext{
${ }^{29}$ For criticism of the UK courts' interpretation of Banković, see J. Williams, 'Al-Skeini: A Flawed Interpretation of Banković,' (2005) 23 Wisconsin ILJ 687; T. Thienel, 'The ECHR in Iraq: The Judgment of the House of Lords in R (Al-Skeini) v. Secretary of State for Defence', (2008) 6 JICJ 115 .

${ }^{30}$ Al-Skeini v UK, supra note 5, concurring opinion of Judge Bonello, paras. 32-3 (original emphasis).

${ }^{31}$ Banković, supra note 2, paras. 75-6.
} 


\subsection{Exceptions to Territoriality}

Reconciling the findings on the exceptions to territoriality is less straightforward. The arguments in Banković centred on the effective control principle, whereas in Al-Skeini the main focus was the state agent authority exception. The decisions can be linked by their reliance on the exercise of public powers by a state in another state's territory as an influential factor, but the difficulty is working out where the exercise of public powers sits $\mathrm{n}$ relation to the two recognised exceptions to territoriality.

In Bankovic the reference to the exercise of public powers was made in summarising the case-law of the Court in which it had recognised the exercise of extraterritorial jurisdiction:

when the respondent state, through the effective control of the relevant territory and its inhabitants abroad as a consequence of military occupation or through the consent, invitation or acquiescence of the government of that territory, exercises all or some of the public powers normally to be exercised by that government. $^{32}$

There is an ambiguity in this passage that could have been fixed with simple punctuation-but should the comma be inserted after "occupation" or after "abroad"? If the comma is read in after "abroad", the exercise of public powers could be equated to the effective control exception, but I do not think that was what the Bankovic Court intended. If the comma is placed after "occupation", it reads as if the Court is maintaining the typical distinction between effective control of territory (or the spatial model of jurisdiction) and a situation where the state's authorities are exercising public powers with the local government's consent/invitation/acquiescence, which can be interpreted as a formulation of the state agent authority exception (or the personal model of jurisdiction). I would argue that this latter interpretation makes more sense, and is more convincingly reconcilable with Al-Skeini. ${ }^{33}$ It would also be more consistent with the surrounding context of the judgment, in which the Court was summarising previous instances of extraterritorial jurisdiction that had included both effective control and state agent authority. The lack of clarity in this crucial section of Banković is regrettable.

\footnotetext{
${ }^{32}$ Ibid., para. 71.

${ }^{33}$ Compare Al-Skeini v UK, supra note 5, para. 135.
} 
In Al-Skeini the exercise of public powers by the UK in Iraq served as the background context for applying the newly articulated state agent authority exception, based on physical power and control over an individual. ${ }^{34}$ Interestingly, the Court did not state any conclusion on whether the UK had effective control over the area. But the UK's responsibility for the exercise of public powers in the region clearly played a significant role in the decision that the applicants' relatives were within UK jurisdiction.

To approach this from a different angle, how would Banković be decided after Al-Skeini? In Al-Skeini the jurisdictional link came from the state agents' authority and control "over individuals killed in the course of its security operations" in circumstances where the UK was found to be responsible for the maintenance of security in the area. The decisive element for applying the Al-Skeini state agent authority formulation to the Banković circumstances is whether it could be said that the NATO pilots exercised physical power and control over the victims. ${ }^{35}$ The victims happened to be in or near the building when it was targeted from the air during what the European Court has described in Medvedyev as an "instantaneous extraterritorial act". ${ }^{36}$ The complexities of the relationship between human rights law and international humanitarian law, and whether or not the strike complied with targeting requirements, are beyond the scope of this note; nonetheless, it seems legally arguable that dropping a bomb on a building during an armed conflict after the requisite precautions have been taken (warnings, proportionality assessments etc) is not an exercise of physical power and control over persons who happen to be on the ground triggering 'jurisdiction' in the ECHR sense.

But is it valid then to distinguish the airstrikes in Bankovic from the ground operations that killed the first five victims in Al-Skeini? Once again, the difference appears to be the background context of the UK's responsibility for the exercise of certain public powers in the area-it was the killing in the course of security operations that brought those five individuals into UK jurisdiction.

This brings us back to effective control. The exercise of public powers was identified in Bankovic as the common thread in cases where the Court has recognised extraterritorial jurisdiction. Does the Al-Skeini formula of physical power and control over an individual, coupled with the exercise of public powers in the area, act as some form of halfway house falling short of effective

\footnotetext{
${ }^{34}$ Ibid., paras. $135-6$.

${ }^{35}$ Al-Skeini v UK, supra note 5, para. 136.

${ }^{36}$ This was to distinguish the circumstances in Medvedyev, supra note 28, from Banković limitations.
} 
control? Does this stretch state agent authority to breaking point in a manner that renders the effective control exception redundant, as the Lords feared? Or is it a new category altogether? It is difficult to conclude on this point without knowing the Court's views on effective control in Al-Skeini.

We will have to await further clarification from the Court to answer these questions. For present purposes, suffice to say that the two cases were decided on quite different arguments arising from quite different factual circumstances, but the differences in legal reasoning between them are not irreconcilable. It cannot be said that Al-Skeini overrules Banković because it appears unlikely the Court would come to a different result deciding Banković now.

\section{Evaluation and Concluding Remarks}

Critics of the jurisprudence on extraterritorial application of human rights treaties, and the ECHR in particular, lament the lack of coherently stated and developed principles, and the repeated preference for a case-by-case, piecemeal approach. As Lord Rodger put it, "the judgments and decisions of the European Court do not speak with one voice". ${ }^{37}$ Al-Skeini presented a much-anticipated opportunity to clarify some of those principles. As the concurring opinion of Judge Bonello indicates, it may have fallen short of expectations in that regard. It cannot be denied that it has clarified (at least to some extent) the Court's position on indivisibility and the fact that the Convention will be held to apply beyond the espace juridique of its parties in appropriate and exceptional circumstances. It has stated more clearly than in the past what it considers to be covered by the state agent authority exception, purportedly identifying the defining principles of that exception from an examination of the Court's case law, rather than formulating novel exceptions.

However, the decision leaves unanswered some key questions on the interrelationship between the effective control exception and the state agent authority exception, and the relevance of the "exercise of public powers" in relation to those exceptions. Could the Court not have said that a situation of belligerent occupation raises a presumption of effective control by the occupying power? Should it have adopted Judge Bonello's functional approach, by which the test for jurisdiction (in all cases, not just extraterritorially) boils down to whether the commission or otherwise of the alleged violation depended on the agents of the state; the question would then arise of whether

\footnotetext{
${ }^{37}$ Al-Skeini v Secretary of State for Defence, supra note 17, para. 67.
} 
it was within the power of the state to punish the perpetrators and compensate the victims. ${ }^{38}$ This bright line approach would perhaps be preferable. ${ }^{39}$

European states might fear that $\mathrm{Al}-\mathrm{Skeini}^{40}$ will open the floodgates to claims of ECHR violations arising from their involvement in military operations outside Europe and around the world, but this would be an overreaction. Al-Skeini confirms that Banković did not close the door on the possibility of applying the Convention outside the territories of the Council of Europe member states, but it stops well short of throwing that door wide open. The decision emphasises the exceptional circumstances that underpinned Al-Skeini (the UK's responsibility for exercising public powers in another state) and reiterates that each case must be decided on its particular facts. Other cases since Banković have also recognised the possibility of jurisdiction arising outside the regional space of the Convention without causing any great rush of litigation or massive expansion of the basically territorial notion of jurisdiction. ${ }^{41}$

Standing back from the legal intricacies of the jurisdictional question, it would be difficult to disagree with the principle emphasised by the applicants and the interveners in Al-Skeini that double standards must not be allowed: states must not be allowed to perpetrate violations on foreign territory which they could not do at home. ${ }^{42}$ In the course of argument the UK had put forward submissions to the effect that imposing the "culturally alien human rights standards" of the ECHR in states outside Europe might breach the principle of self-determination and lead to accusations of human rights imperialism. ${ }^{43} \mathrm{It}$ even suggested that applying the ECHR in Iraq would require amendments to the Iraqi Constitution, in breach of the UK's obligations as an occupying power to respect the laws in force there. ${ }^{44}$

It is troubling that arguments like these had found some favour in the House of Lords, with Lord Rodger proclaiming that it would be "manifestly absurd" to expect the UK to apply the ECHR in the "utterly different society

\footnotetext{
${ }^{38}$ Al-Skeini v UK, supra note 5, concurring opinion of Judge Bonello.

${ }^{39}$ See further Assanidze v Georgia [2004] ECHR 71503/01, concurring opinion of Judge Loucaides; Ilaşcu v Moldova and Russia [2004] ECHR 48787/99, dissenting opinion of Judge Kovler.

${ }^{40}$ Together with Al-Jedda $v$ UK [2011] ECHR 27021/08, which was issued on the same day and also found a jurisdictional link between the UK and an Iraqi detainee, such that the ECHR applied extraterritorially.

${ }^{41}$ See e.g. cases mentioned supra note 28.

${ }^{42}$ See also Issa $v$ Turkey, supra note 18, para. 71.

${ }^{43}$ Al-Skeini v UK, supra note 5, para. 110.

${ }^{44}$ Ibid., para. 114.
} 
of southern Iraq". ${ }^{4}$ With respect, it seems far more absurd to entertain an argument that the UK's international obligations as an occupying power would require it to refrain from upholding such fundamental rights as those at issue in the case, the right to life and freedom from torture-and particularly when the Iraqi applicants themselves sought the enforcement of those rights. Thankfully, Strasbourg rejected this line of argument. Its inherent hypocrisy was sharply and eloquently exposed by Judge Bonello:

Being bountiful with military imperialism but bashful of the stigma of human rights imperialism, sounds to me like not resisting sufficiently the urge to frequent the lower neighbourhoods of political inconstancy. For my part, I believe that those who export war ought to see to the parallel export of guarantees against the atrocities of war. And then, if necessary, bear with some fortitude the opprobrium of being labelled human rights imperialists. ${ }^{46}$

Only time will tell whether Al-Skeini will overtake Banković as a new watershed authority in the Strasbourg jurisprudence, in terms of the interpretation of Article 1 . At the very least, however, supported by Al-Jedda, it stands as a strong statement that members of the armed forces involved in military operations abroad, and the states parties to ECHR that send them, cannot necessarily shelter behind Article 1 and Banković to avoid being held responsible for human rights violations outside national territory. Each case will inevitably continue to turn on its own facts, but it can be hoped that the outcome in Al-Skeini will impact upon domestic decision-making and undo some of the residual confusion left behind after Banković.

\footnotetext{
${ }^{45}$ Al-Skeini v Secretary of State for Defence, supra note 17, para. 78.

${ }^{46}$ Al-Skeini v UK, supra note 5, concurring opinion of Judge Bonello, paras. 37-8.
} 